\title{
Relationships between physical and chemical factors and aquatic macroinvertebrates in perennial streams in the arid northern mountain basin El Batinah, Oman
}

\author{
S. Boulaaba, ${ }^{1}$ S. Zrelli, ${ }^{1}$ M. Boumaiza, ${ }^{1}$ B. Rossaro \\ ${ }^{1}$ Laboratoire d'Hydrobiologie, Bizerte, Tunisie; ${ }^{2}$ DeFENS, Dipartimento di Scienze per gli Alimenti, \\ la Nutrizione e l'Ambiente, Università di Milano, Italy
}

\begin{abstract}
The relationships between physical properties, water chemistry and aquatic macroinvertebrates were investigated in riffles of four perennial streams in the arid northern Oman. Samples were collected monthly in autumn, winter and spring with a Surber net. Thirty two invertebrate taxa were recorded, most species are widely distributed, but few species with very restricted distribution were also captured. Diptera followed by Pulmonata, Coleoptera and Odonata were the most represented taxa, Trichoptera and Heteroptera were a significant component only in one station (the Fezeh), where the lowest mean water temperature $\left(23^{\circ} \mathrm{C}\right)$ was recorded. In the dry months from May to October, aquatic macroinvertebrates were completely absent. In order to summarise the community response some biotic indices were calculated. The highest diversity was observed in the Fezeh station. A seasonal gradient was also observed, with the highest diversity values in January, April, and December. The low faunal diversity was attributed to the high air and water temperature and the hydrological regime instability. A between station and a between month coinertia analysis was carried out, to analyse the response to spatial and season-
\end{abstract}

Correspondence: Bruno Rossaro, DeFENS, Dipartimento di Scienze per gli Alimenti, la Nutrizione e l'Ambiente, Università di Milano, via G. Celoria 2, 20133 Milano, Italy.

Tel.: +39.02.503.16734 - Fax: +39.02 .503 .16748 .

E-mail: bruno.rossaro@unimi.it

Key words: Arabia, Oman, arid zone, wadi, macroinvertebrates.

Acknowledgements: we would like to thank Dr. Touaylia Samir and Dr. Khaloufi Noureddine for help in the identification of the chironomid larvae and valuable comments; Hydrobiology Laboratory of Bizerte Faculty for abiotic parameters.

Received for publication: 21 September 2013.

Revision received: 25 November 2013.

Accepted for publication: 11 December 2013.

(C) Copyright S. Boulaaba et al., 2014

Licensee PAGEPress, Italy

Journal of Entomological and Acarological Research 2014; 46:1936

doi:10.4081/jear.2014.1936

This article is distributed under the terms of the Creative Commons Attribution Noncommercial License (by-nc 3.0) which permits any noncommercial use, distribution, and reproduction in any medium, provided the original author(s) and source are credited. al factors. The first coinertia axis was correlated with altitude and substrate composition, while the second axis was correlated with air and water temperature.

The present research emphasizes the urgency for preserving the less disturbed wadis in arid zones, because, despite their species poorness, their uniqueness in faunal composition requires special attention. The presence of few endemic species with very restricted distribution highlights the topicality and the value in investigating these areas, allowing the increase of our knowledge on biodiversity, ecology and biogeography about the benthic macroinvertebrates living in these extreme habitats.

\section{Introduction}

Relationships between benthic macroinvertebrates and environmental variables were often matter of investigation (Depiereux et al., 1983; Wright et al., 1984; Ormerod, 1987; Ormerod \& Edwards, 1987; Boulton \& Lake 1992a, 1992b; Boumaïza 1994; Gower et al., 1994; Tate \& Heiny, 1995), inducing to consider macroinvertebrates communities as good indicators of water quality conditions (De Shon, 1995; Resh, 1995). Furthermore, studies of temporal variation in the community structure of streams (Fisher et al., 1982; Scrimgeour \& Winterbourn, 1989) indicated that physical disturbances (e.g., water temperature, substrate composition and the hydrological regime) are important determinants in lotic systems (Sousa, 1984; Resh et al., 1988).

Within the framework of the study of relationships between environmental factors and community composition freshwater ecosystems in extreme arid zones require special attention .

The chain of Hajar mountain extending from northern Oman and the eastern United Arab Emirates is a part of the Arabian Highlands. The World Wildlife Fund for Nature identified this area as part of the Global 200 Ecoregions, i.e. it a priority area for biodiversity research and conservation (Launay \& Jungius, 2001). Although rainfall in the region is low and infrequent (Burt, 2003) there are numerous permanent sources generating spring-fed streams. Most of them are intermittent, with flow alternating between the surface and the hyporheic (alluvial) zone, they are known as wadis (from the Arabic wadian) and differ from streams of temperate zones, since the spatially infrequent surface flows act as islands for organisms with aquatic life stages (Brooks, 2000).

There are few contributions to the knowledge of benthic macroinvertebrates inhabiting wadis. Recently investigated areas are in North Africa (Arab et al., 2004; Zerguine et al., 2009; Chaib et al., 2013a, 2013b). Unfortunately, knowledge of freshwater fauna in the Arabian Peninsula is extremely limited (Victor \& Al-Mahrouqi, 1996). In the 
Oman region aquatic macroinvertebrates were previously investigated (Burt, 2003), but all groups were identified to family or at most to genus level.

The purpose of this study was to examine wadis with permanent flow in the Oman region, taxa identification was deepened at the species level whenever possible and relations between environmental factors and faunal composition were investigated with multivariate coinertia analysis.

\section{Materials and methods}

\section{Study site}

The sultanate of Oman lies on the eastern edge of the Arabian Peninsula. Relief in the sultanate Oman varies from the jagged mountains in the north, to the flat lying plains in the central part. The rest of the north Oman is occupied by the rugged Al Hajar Mountains that lead eastward to El Batinah plain. Alluvial fans of rivers and pediments at the base of the mountains formed El Batinah plain as a result of the deposition of materials carried by surface water.

Study sites were located in El Batinah Mountains, North-West of the village of Sohar, Oman (Figure 1). In the study area, farming is the major human activity and cultivated plants are date palm, Phoenix dactylifera L (Arecaceae), lemon, Citrus lemon L (Rutaceae) and alfal- fa, Medicago sativa L (Fabaceae). Waters from the studied streams are diverted by a falaj to irrigate the farms.

Four sites (Figure 1) in the Batinah mountains, Al Jezzy (station J., $24^{\circ} 30^{\prime} 29.01^{\prime \prime} \mathrm{N}$ and $56^{\circ} 26^{\prime} 48.83$ " E), Hyoul (station H., 24 $21^{\circ} 30.45^{\prime \prime} \mathrm{N}$ and $56^{\circ} 21^{\prime} 41.60 " \mathrm{E}$ ), Rohob (station R, 24 ${ }^{\circ} 22^{\prime} 13.19 " \mathrm{~N}$ and $56^{\circ} 19^{\prime} 52.47^{\prime \prime} \mathrm{E}$ ) and Fezeh (station F., $24^{\circ} 30^{\prime} 29.00^{\prime \prime} \mathrm{N}$ and $56^{\circ} 26^{\prime} 48.83^{\prime \prime}$ E), were selected for this study. The physical and chemical characteristics of the sampled stations are in Table 1. Aquatic macrophytes are present in all stations and are represented by only one species Potamogeton nodosus.

\section{Sampling method}

The samples of bottom fauna were taken by using a Surber net (250 $\mu \mathrm{m}$ mesh size). Sampling was performed during $5 \mathrm{~min}$, and care was taken to include all available microhabitats within a representative 50 m. Samples were collected in each site in January, February, March, April, October, November and December. Benthic macroinvertebrates were identified to the lowest possible taxonomic level, i.e. genus/species. Four replicate samples were taken in each site. Samples were preserved in $75 \%$ ethyl alcohol.

The following taxonomic keys were used in species identification (Olmi, 1978; Tamanini, 1979; Girod et al., 1980; Pirisinu, 1981; Moretti, 1983; Nocentini, 1985; Friday, 1988; Heidemann \& Seidenbush, 2002; Vårdal et al., 2002; Cham, 2007, 2009).

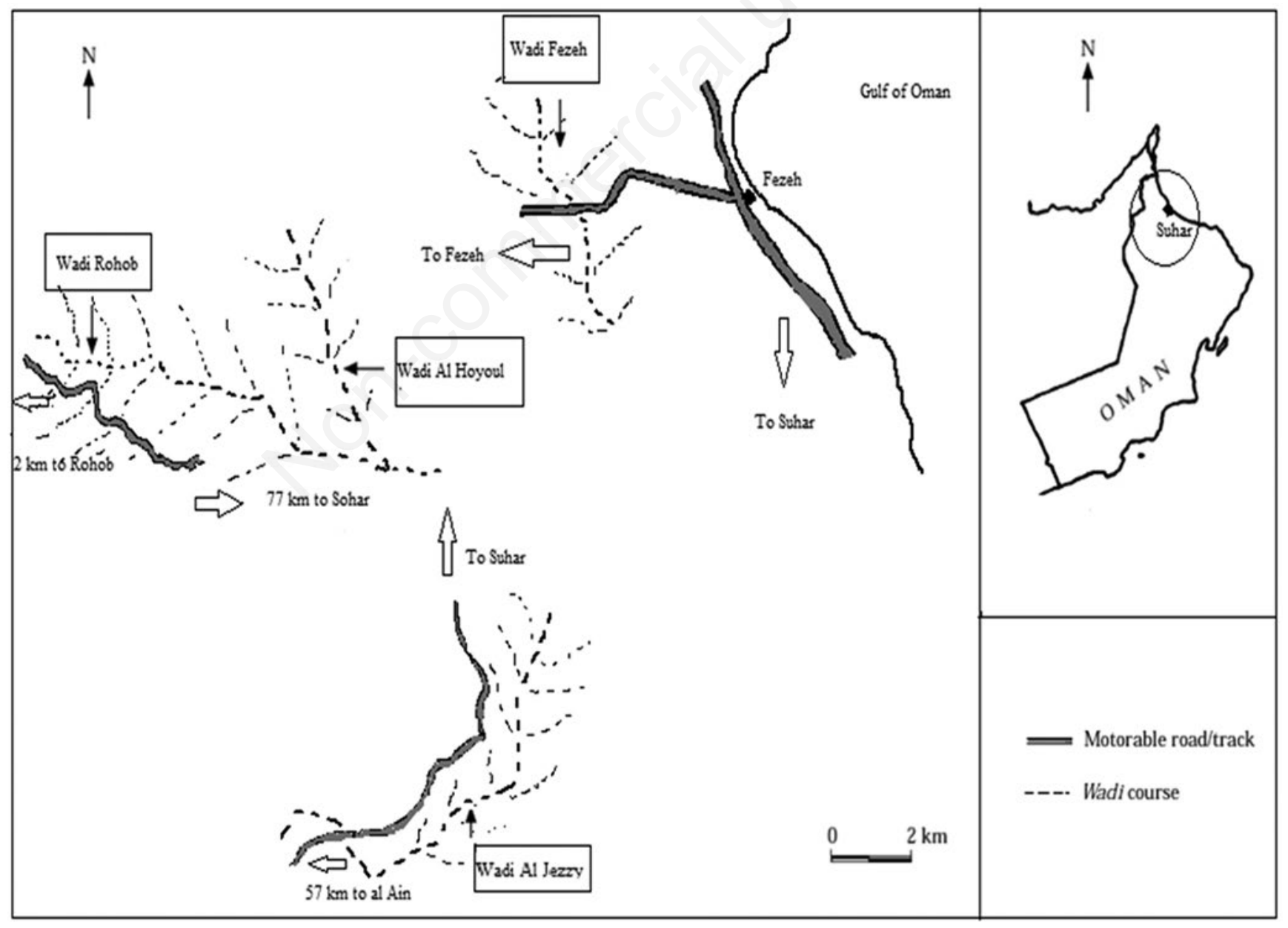

Figure 1. Map of the area. Rectangles show the sampled stations in Al Hajar Mountains of Batinah; inset shows Oman and the location of Sohar town. Source: Sultanate of Oman topographic maps. 


\section{Environmental variables}

Environmental data, describing Wadi morphology and water quality, were collected on each sampling date at each site. The data measured in the field were: depth (m), current velocity (CV, $\mathrm{m} \mathrm{s}^{-1}$ ), air (tair) and water $\left(\mathrm{tH}_{2} \mathrm{O}\right)$ temperature $\left({ }^{\circ} \mathrm{C}\right)$, conductivity (cond, $\mu \mathrm{S} \mathrm{cm}-1$ ), oxygen $\left(\mathrm{O}_{2}, \mathrm{mg} \mathrm{L}^{-1}\right)$, $\mathrm{pH}$, width $(\mathrm{m})$, dominant substrate, coded as: sand (2-5 $\mathrm{mm})$; gravel $(5-25 \mathrm{~mm})$; pebble $(25-50 \mathrm{~mm})$; rock $(50-100 \mathrm{~mm})$; cobble (100-250 mm); boulder ( $>250 \mathrm{~mm})$. Substrate composition was coded as three binary variables (boulder+cobble+rock, gravel+pebble, sand+silt). Altitude, longitude and latitude were also included in data analysis.

\section{Data analysis}

Several indices and scores were used to examine changes in the invertebrate species diversity with time and in relation to fluctuations in climatic events. Diversity indices are mathematical expressions that use three components of community structure, namely richness (number of categories present), evenness (uniformity in the distribution of individuals among categories) and abundance (total number of organisms present), to describe the response of a community to the quality of the environment (Zar, 1984; Metcalfe-Smith, 1996). The most widely used diversity index is the Shannon-Wiener index $\left(H^{\prime}\right)$ because it is stable in any spatial distribution and it is not influenced by rare species (Ludwig \& Reynold, 1988). The higher the value of $H^{\prime}$, the greater the diversity and, supposedly, the healthier the environment (MetcalfeSmith, 1996). However (Bendati et al., 1998) a few individuals evenly distributed among several species could give a relatively high index of diversity even though a habitat is heavily polluted. Despite this problem, the calculation of Shannon diversity index, in combination with the other indicators of community structure (i.e., richness, evenness and abundance), allows to compare taxa assemblages of different sites.

To investigate the relation between environmental variables and species distribution a co-inertia analysis (CoIA) - a two-table ordination method - was performed using the Ade-4 package in the R environment (Legendre \& Legendre, 1998; Borcard et al., 2011). This multivariate analysis tool is used to ordinate samples by searching for a co-structure maximizing the covariance between 2 matrices prepared as sites $\mathrm{x}$ environmental variables and sites $\mathrm{x}$ species. The CoIA factorial map explains the part of variability similar to each separate analysis, and the 2 coordinate systems are superimposed to emphasize the relationship between the 2 matrices. In the present case, 14 environmental variables were related to 32 benthic macroinvertebrate species in 21 samples.

A between-stations and a between months co-inertia analyses (bca) were carried out to allow a plot of the mean scores of each station and of each month (Franquet et al., 1995); the bca is a co-inertia analysis with instrumental variables: first a correspondence analysis is carried out on the fitted variables of interest (the $\log (x+1)$ transformed species matrix) after the regression on an instrumental variable, then a principal component analysis is carried out on the fitted environmental variables after the regression on the same instrumental variable (Pech \& Laloë, 1997); then the results of the two analyses are entered in the co-inertia analysis (Borcard et al., 2011). In the present case the instrumental variable is a factor with four levels (in bca between stations the stations investigated) or a factor with six levels (in bca between months the months sampled) (Lupi et al., 2013).

The R Project for Statistical Computing ${ }^{\circledR}$ (Version 2.15.1) was used to calculate Diversity and coinertia.

\section{Results}

Table 1 summarises the physical and chemical conditions of the investigated stations, high air and water temperatures were recorded, air temperatures often above $30^{\circ} \mathrm{C}$. Stream water fed by springs rich in ophiolites was responsible of a $\mathrm{pH}$ above 8 . A low number of taxa as observed, thirty two invertebrate taxa in 786 specimens were collected during the investigated period. Table 2 gives the list of the species found in the four stations. The overall abundance of fauna was highest at Al Jezzy (326 individuals=41\%) and lowest at Rohob (95 individuals $=12 \%$ ). Wide fluctuations in the abundance of major taxonomic groups were observed among stations and months. Pulmonata, Trichoptera and Diptera were present in the 4 stations (Figure 2). Aquatic insects were more abundant representing over $87.5 \%$ and $79.5 \%$ respectively of the overall taxa and individuals recorded. Coleoptera were represented by eleven species, some of them occurred as a single specimen, for example, Cybister sp. in station Fezeh and Laccophilus sp. in Al Jezzy. Diptera formed a major component of fauna in this study, five species were recorded, Chironomidae were repre-

Table 1. Summary of the physical and chemical properties of the stations investigated, variables measured from November 2006 to April 2007.

\begin{tabular}{|c|c|c|c|c|c|c|c|c|c|c|c|c|}
\hline \multirow[t]{2}{*}{ Properties } & \multicolumn{3}{|c|}{ Al Jezay } & \multicolumn{3}{|c|}{ Hayoul } & \multicolumn{3}{|c|}{ Rohob } & \multicolumn{3}{|c|}{ Fezeh } \\
\hline & Mean \pm SE & Min & Max & Mean \pm SE & Min & Max & Mean \pm SE & Min & Max & Mean $\pm S E$ & Min & Max \\
\hline Altitude (m) & 317 & & & 322 & & & 416 & & & 122 & & \\
\hline Source distance (km) & 6.0 & & & 4.4 & & & 1.7 & & & 1.5 & & \\
\hline \multicolumn{13}{|l|}{ Physical } \\
\hline Air temperature $\left({ }^{\circ} \mathrm{C}\right)$ & $34.40 \pm 3.91$ & 28 & 38 & $34.60 \pm 4.09$ & 28 & 38 & $34.00 \pm 4.18$ & 28 & 39 & $34.40 \pm 3.78$ & 29 & 38 \\
\hline Water temperature $\left({ }^{\circ} \mathrm{C}\right)$ & $26.60 \pm 1.67$ & 24 & 28 & $26.30 \pm 3.04$ & 20 & 27 & $25.98 \pm 1.71$ & 24 & 28 & $23.94 \pm 2.20$ & 20 & 25 \\
\hline Depth (m) & $0.24 \pm 0.05$ & 0.2 & 0.3 & $0.24 \pm 0.05$ & 0.2 & 0.3 & $0.22 \pm 0.03$ & 0.2 & 0.25 & $0.34 \pm 0.23$ & 0.15 & 0.6 \\
\hline Width (m) & $4.88 \pm 4.89$ & 3.0 & 15 & $2.00 \pm 0.00$ & 2.0 & 2.0 & $2.40 \pm 0.54$ & 2.0 & 3.0 & $3.60 \pm 0.54$ & 3.0 & 4.0 \\
\hline Current velocity $\left(\mathrm{m} \mathrm{s}^{-1}\right)$ & $0.96 \pm 0.21$ & 0.6 & 1.2 & $1.28 \pm 0.17$ & 1.0 & 1.5 & $0.76 \pm 0.28$ & 0.3 & 1.0 & $0.50 \pm 0.35$ & 0.25 & 1.1 \\
\hline Substratum & Gravel, sand & & & Sand & & & Boulder, grave & & & Sand & & \\
\hline \multicolumn{13}{|l|}{ Chemical } \\
\hline Hydrogen-ion conc. (pH) & $8.466 \pm 0.06$ & 8.4 & 8.53 & $8.460 \pm 0.46$ & 7.4 & 8.5 & $8.314 \pm 0.44$ & 7.78 & 8.7 & $7.794 \pm 0.24$ & 7.5 & 8 \\
\hline Conductivity $\left(\mu \mathrm{S} \mathrm{cm}^{-1}\right)$ & $506.4 \pm 12.64$ & - & 515 & $511.6 \pm 8.32$ & 501 & 520 & $494.8 \pm 45.55$ & 415 & 530 & $554.8 \pm 44.56$ & 505 & 603 \\
\hline Dissolved oxygen (mg L $\left.\mathrm{L}^{-1}\right)$ & $6.012 \pm 0.42$ & 5.3 & 6.4 & $5.72 \pm 0.32$ & 5.3 & 6.1 & $5.1 \pm 0.23$ & 4.7 & 5.3 & $5.42 \pm 0.14$ & 5.2 & 5.6 \\
\hline
\end{tabular}

SE, standard error. 
sented by two taxa, Polypedilum bifurcatum and Chironomus calipterus; only one Tabanid, Tabanus sp. was found (Fezeh). Simulium (Simuliidae), represented by two species ( $S$. buettiketi and $S$. ruficorne), occurred in all stations. The Odonata were represented by nine species and were present in all stations except Rohob. Trichoptera were represented by three species: Hydropsyche atrax, Setodes acutus and Stenophylax sp.; the first species occurred in four stations while the last occurred only at Fezeh.

Most of the species found have a wide distribution as described in the Fauna Europaea database (http://www.faunaeur.org/); in most cases their distribution is conditioned by their preferences for high water temperatures and are distributed only in south European countries (C. calipterus), three endemic species were found with a very restricted distribution, the Chironomid Polypedilum bifurcatum, actually known only from Oman and Kenya (Vårdal et al., 2002), the Trichopteran Setodes acutus known only from Morocco (Dakki, 197980) and Simulium buettikeri known only from Oman and Afganistan (Adler \& Crosskey, 2013).

The highest species diversity measured by the Shannon diversity index was found in Fezeh, Al Jezzy had the lowest diversity (Table 3). Examining Figure 3 it is possible to observe that Simuliidae and Chironomidae were more abundant in Winter and were absent in March and April, only Pulmonata were present in March. The species richness was the highest in the cool months. The seasonal distribution emphasised the poorness of fauna in March, a well diversified fauna in January and a dominance of Coleoptera in December.
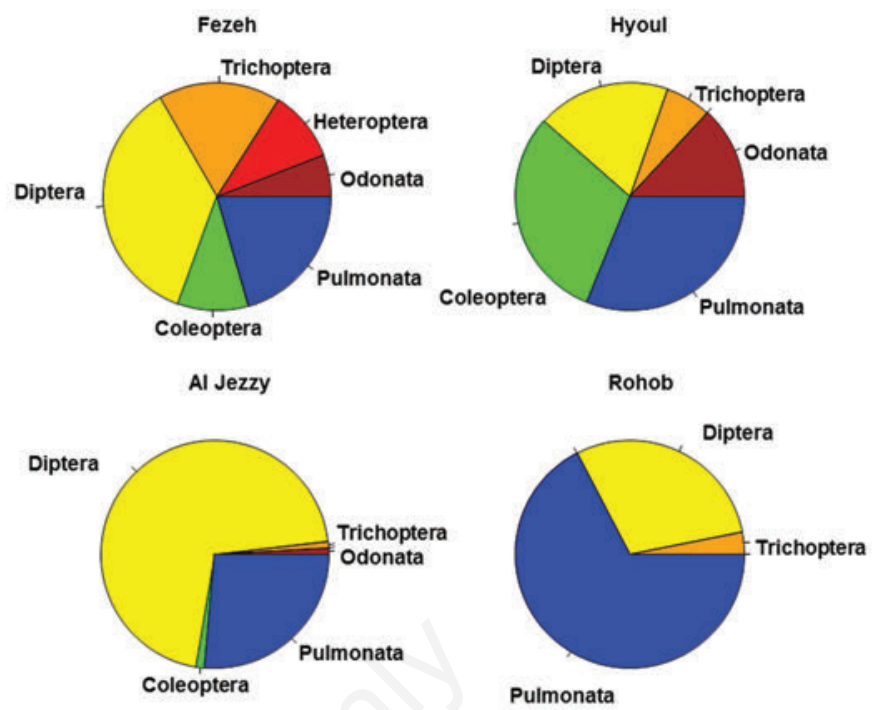

Figure 2. Taxa composition in the four stations: Al Jezz, Fezeh, Hayoul, Rohob.

Table 2. List of the species found.

\begin{tabular}{|c|c|c|c|c|}
\hline Order & Family & Abbreviation & Species & Author, year \\
\hline Odonata & $\begin{array}{l}\text { Aeshnidae } \\
\text { Gomphidae } \\
\text { Libellulidae } \\
\text { Macromiidae }\end{array}$ & $\begin{array}{l}\text { A.imp } \\
\text { A.par } \\
\text { Boyer } \\
\text { H.ephipp } \\
\text { P.genei } \\
\text { O.sabin } \\
\text { S.fonsc } \\
\text { T.kirb } \\
\text { M.splend }\end{array}$ & $\begin{array}{c}\text { Anax imperator } \\
\text { Anax parthenope } \\
\text { Boyeria irene } \\
\text { Hemianax ephippiger } \\
\text { Paragomphus genei } \\
\text { Orthetrum sabina } \\
\text { Sympetrum fonscolombii } \\
\text { Trithemis kirbyi } \\
\text { Macromia splendens }\end{array}$ & $\begin{array}{c}\text { Leach, 1815 } \\
\text { (Selys, 1839) } \\
\text { (Fonscolombe, 1838) } \\
\text { (Brurmeister, 1839) } \\
\text { (Selys, 1841) } \\
\text { (Drury, 1773) } \\
\text { (Selys, 1840) } \\
\text { (Seyls, 1891) } \\
\text { (Pictet, 1834) }\end{array}$ \\
\hline Heteroptera & $\begin{array}{l}\text { Nepidae } \\
\text { Pleidae }\end{array}$ & $\begin{array}{c}\text { Nepa } \\
\text { Plea }\end{array}$ & $\begin{array}{c}\text { Nepa sp } \\
\text { Plea sp }\end{array}$ & \\
\hline Trichoptera & Hydropsychidae & $\begin{array}{l}\text { H.atra } \\
\text { S.acut } \\
\text { Stenoph }\end{array}$ & $\begin{array}{l}\text { Diplectrona atra } \\
\text { Setodes acutus } \\
\text { Stenophylax sp }\end{array}$ & $\begin{array}{c}\text { McLachan, } 1878 \\
\text { Navâs, } 1936\end{array}$ \\
\hline Diptera & $\begin{array}{l}\text { Chironomidae } \\
\text { Simuliidae } \\
\text { Tabanidae }\end{array}$ & $\begin{array}{l}\text { C.calip } \\
\text { P.bifur } \\
\text { S.buett } \\
\text { S.rufic } \\
\text { Taban }\end{array}$ & $\begin{array}{l}\text { Chironomus calipterus } \\
\text { Polypedilum bifurcatum } \\
\text { Simulium buettikeri* }^{*} \\
\text { Simulium ruficorne } \\
\text { Tabanus sp }\end{array}$ & $\begin{array}{c}\text { Kieffer, } 1908 \\
\text { Cranston, } 1989 \\
\text { Crosskey \& Roberts, } 1994 \\
\text { Macquart, } 1938\end{array}$ \\
\hline Coleoptera & $\begin{array}{l}\text { Dryopidae } \\
\text { Dytiscidae } \\
\text { Gyrinidae } \\
\text { Hydraenidae } \\
\text { Hydrophilidae }\end{array}$ & $\begin{array}{l}\text { Aulon } \\
\text { Dryops } \\
\text { Cybis } \\
\text { H.vitic } \\
\text { Laccoph } \\
\text { Orectoc } \\
\text { Hydraen } \\
\text { H.carb } \\
\text { Hydrob } \\
\text { Laccob } \\
\text { Parac }\end{array}$ & $\begin{array}{l}\text { Aulongyrus } \mathrm{sp} \\
\text { Dryops } \mathrm{sp} \\
\text { Cybister } \mathrm{sp} \\
\text { Hydaticus vittatus } \\
\text { Laccophilus } \mathrm{sp} \\
\text { Orectochilus } \mathrm{sp} \\
\text { Hydraena } \mathrm{sp} \\
\text { Hydrochara caraboides } \\
\text { Hydrobius } \mathrm{sp} \\
\text { Laccobius } \mathrm{sp} \\
\text { Paracymus } \mathrm{sp}\end{array}$ & (Linnaeus, 1758) \\
\hline Pulmonata & $\begin{array}{l}\text { Lymnaeidae } \\
\text { Thiaridae }\end{array}$ & $\begin{array}{l}\text { R.ovat } \\
\text { M.tuber }\end{array}$ & $\begin{array}{c}\text { Radix balthica } \\
\text { Melanoides tuberculatus }\end{array}$ & $\begin{array}{l}\text { Draparnaud, } 1805 \\
\text { (O.F. Muller, 1774) }\end{array}$ \\
\hline
\end{tabular}

*Species with a restricted distribution area, see text for other explanation. 
Co-inertia analysis (Table 4) gave a first coinertia axis explaining $53 \%$ of total inertia, and a second axis explaining $17 \%$. The first axis separated the Fezeh from all the others stations (Table 5, Figure 4); the variables responsible (Table 6) were geographic position, altitude, depth, width and conductivity (Figure 5), but not source distance (Table 1). Substrate was also responsible of the different fauna composition along the first axis, with stations characterised by large size substrates (boulders, grav- el) separated from fine size substrates stations. Stations at higher altitude had lower depth and conductivity. The second axis separated the other three stations to each other, Hyoul $(\mathrm{H})$ and Al Jezzy $(\mathrm{J})$ having opposite scores (Figure 4). Different air, water temperature and oxygen content explained the separation of sites according to the second axis. The separation of species (Table 7, Figure 6) was emphasised along the first axis above all, with species characterising lowland sites on the left
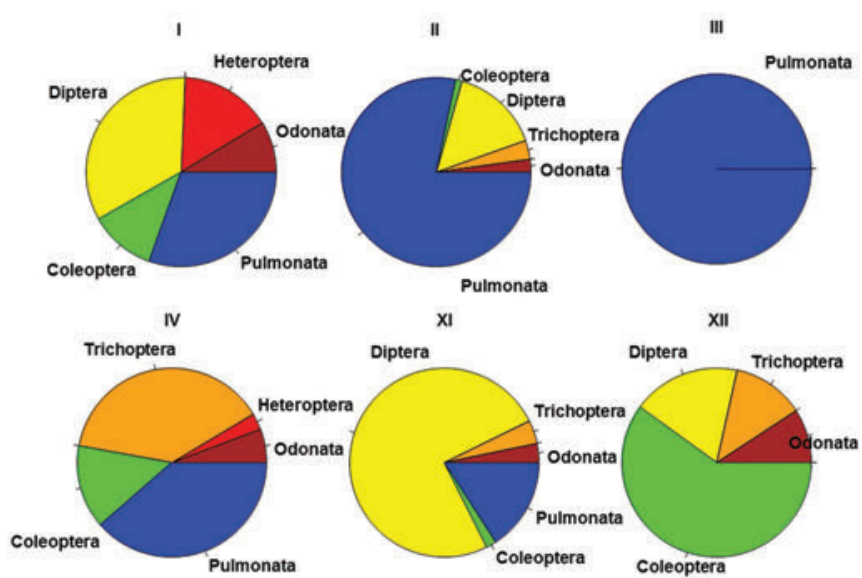

$\mathbf{x}$

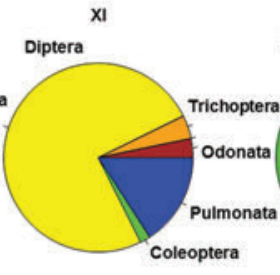

XII

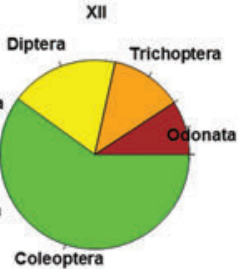

Figure 3. Taxa composition in the six months, months expressed by Roman numbers.

Table 3. Mean number of specimens, taxa and diversity indices.

\begin{tabular}{lccccc} 
& No. index & No. taxa & Shannon & Evenness & 1-Simpson \\
Fezeh & 44 & 7 & 1.372 & 0.707 & 0.621 \\
Hyoul & 24 & 5 & 1.182 & 0.841 & 0.615 \\
\hline Al Jezzy & 65 & 3 & 0.331 & 0.710 & 0.193 \\
Rohob & 19 & 2 & 0.711 & 0.923 & 0.442 \\
\hline
\end{tabular}

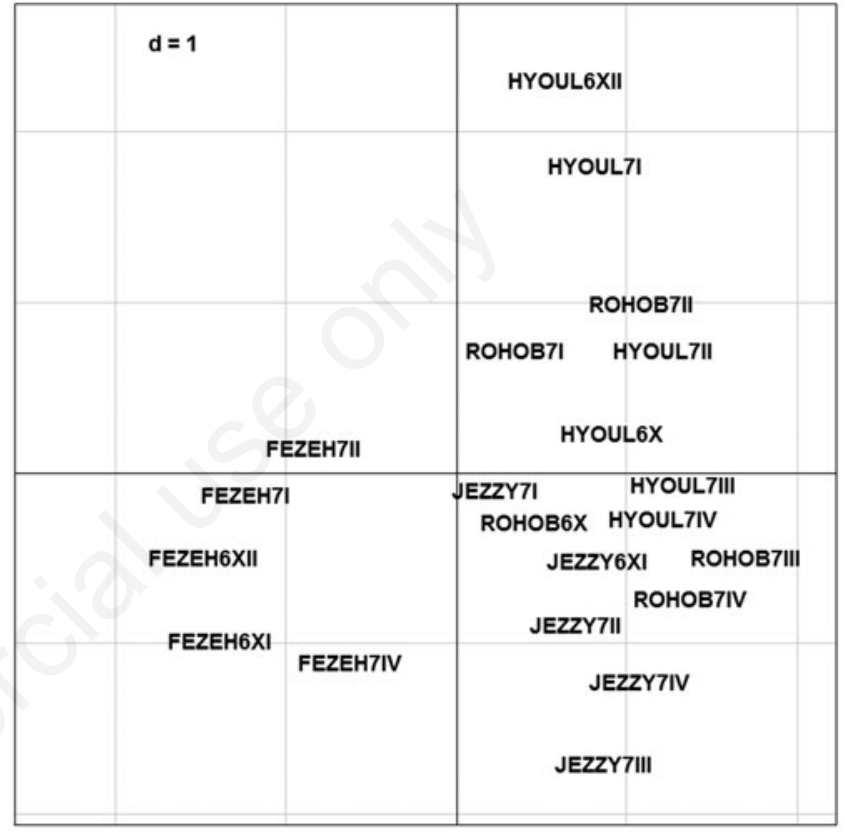

Figure 4. Co-inertia analysis, plot of sites (according to species table) in the first 2 axes; sites abbreviations include the name of station, year (6=2006; 7=2007), month=I, II, III,IV, XI, XII.

Table 4. Co-inertia analysis results: total inertia (Tot in), coefficient of correlation between the two tables Y and Z (RV), eigenvalues (eig), percentage of variance (\%), covariance (covar), standard deviation of the two sets of sites scores on the co-inertia axes (sdY, sdZ) and correlations between the two sets of site scores (corr). The inertia of the species table (Ycoa) and of the environmental data table (Zpca) is also given. The inertia (inertia) of the cumulated projections of the $\mathrm{Y}$ and $\mathrm{Z}$ tables as projected in the co-inertia analysis are compared with the maximum inertia of the axes of the separate ordinations (max), the ratio of these values measures the concordance between the 2 projections (ratio).

\begin{tabular}{|c|c|c|c|c|c|c|}
\hline Tot in & $\begin{array}{c}3.907 \\
\text { Eig }\end{array}$ & $\begin{array}{l}\text { RV } \\
(\%)\end{array}$ & $\begin{array}{l}0.385 \\
\text { covar }\end{array}$ & $s d Y$ & $\mathrm{sd} Z$ & Corr \\
\hline axis 1 & 2.053 & 52.551 & 1.433 & 0.644 & 2.536 & 0.877 \\
\hline axis 2 & 0.657 & 16.806 & 0.810 & 0.669 & 1.514 & 0.800 \\
\hline axis 3 & 0.524 & 13.415 & 0.724 & 0.733 & 1.155 & 0.856 \\
\hline \multirow[t]{2}{*}{ axis 4} & 0.356 & 9.111 & 0.597 & 0.475 & 1.502 & 0.836 \\
\hline & inertia & $\begin{array}{l}\text { Ycoa } \\
\max \end{array}$ & ratio & inertia & $\begin{array}{l}\text { Zpca } \\
\text { max }\end{array}$ & ratio \\
\hline axis 1 & 0.415 & 0.682 & 0.608 & 6.430 & 6.829 & 0.942 \\
\hline axis $1+2$ & 0.863 & 1.284 & 0.672 & 8.723 & 9.535 & 0.915 \\
\hline axis $1+2+3$ & 1.400 & 1.785 & 0.784 & 10.057 & 11.257 & 0.893 \\
\hline axis $1+2+3+4$ & 1.625 & 2.210 & 0.736 & 12.313 & 12.433 & 0.990 \\
\hline
\end{tabular}


(Heteroptera, Chironomus calipterus; Figures 2 and 6) and species characterising the sites at highest altitude on the right (some Odonata, Simulium spp.). Between sites coinertia still better evidenced the ordination of stations (Figure 7), separating Fezeh and Hayoul from Al Jezzy and Rohob, according to fauna composition, Fezeh and Al Jezzy from Hayoul and Rohob according to environmental variables, only Fezeh was clearly separated according to all variables. Between months coinertia (Figure 8) allowed to separate the cold months (November, December, January) from the warmer ones (February, March, April).

\section{Discussion and conclusions}

Benthic macroinvertebrates in running waters in arid zones are poorly known (Arab et al., 2004; Chaib et al., 2013a, 2013b).

A review of mean monthly air temperatures for the period 1979 to 2007 at Sohar, showed that hot months are from April to August, while cool months are from October to February; March and September have transitional temperatures. The present study from November 2006 to April 2007 included all these temperature characteristics of the region.

The air and water temperature were confirmed as an important factor influencing the ecology of these streams. When the air temperature was high during hot months, the abundance of invertebrates in the streams was low. There was an increase in abundance when the air and water temperature were almost the same in the cool months. The dominant invertebrates in the stream, both as total number of taxa and abundance, were insect larvae, and air temperature restricting the breeding activity of adults to cooler months could explain this seasonal increase in abundance. In the hot season from May to October the fauna is totally absent. It is interesting to note that Trichoptera and Heteroptera are significantly present (Figure 2) in the Fezeh station, characterised by the lowest water temperature (Table 1).

Flooding, the most important natural event is catastrophic (Ormerod, 1987), altering the physical structure of the stream as well
Table 5. Co-inertia analysis results, scores of the stations based on species (left) and environmental (right) tables in the first two axes.

\begin{tabular}{lrrrr} 
& \multicolumn{2}{c}{$\begin{array}{c}\text { Species scores } \\
\text { axis1 }\end{array}$} & axis2 & Env variables scores \\
Fezeh & -1.322 & 0.073 & -1.327 & -0.135 \\
Hyoul & 0.606 & 1.279 & 0.799 & 1.038 \\
\hline Al Jezzy & 0.926 & -1.610 & 0.619 & -1.761 \\
Rohob & 0.771 & -0.394 & 0.826 & 0.683 \\
\hline
\end{tabular}

Env, environmental.

Table 6. Co-inertia analysis results, scores of the environmental variables in the first four axes.

\begin{tabular}{lrrrr} 
& RS1 & RS2 & RS3 & RS4 \\
Latitude & -0.224 & -0.279 & 0.040 & -0.340 \\
Longitude & -0.232 & -0.170 & 0.046 & -0.342 \\
\hline Altitude & 0.375 & -0.002 & 0.145 & 0.094 \\
Width & -0.292 & -0.231 & -0.010 & -0.101 \\
\hline Depth & -0.161 & 0.002 & 0.570 & 0.316 \\
CV & 0.282 & 0.111 & -0.258 & 0.060 \\
\hline Boulder & 0.385 & 0.076 & 0.189 & 0.029 \\
Gravel & 0.385 & 0.076 & 0.189 & 0.029 \\
\hline Sand & -0.181 & 0.228 & -0.279 & 0.390 \\
T air & 0.166 & -0.532 & -0.297 & 0.009 \\
\hline T water & 0.290 & -0.637 & 0.219 & 0.166 \\
pH & 0.236 & 0.062 & -0.077 & -0.439 \\
\hline $\mathrm{O}_{2}$ & 0.087 & 0.257 & 0.371 & -0.494 \\
Cond & -0.248 & -0.077 & 0.392 & 0.162 \\
\hline
\end{tabular}

$\mathrm{CV}$, current velocity; T, temperature; Cond, conductivity.

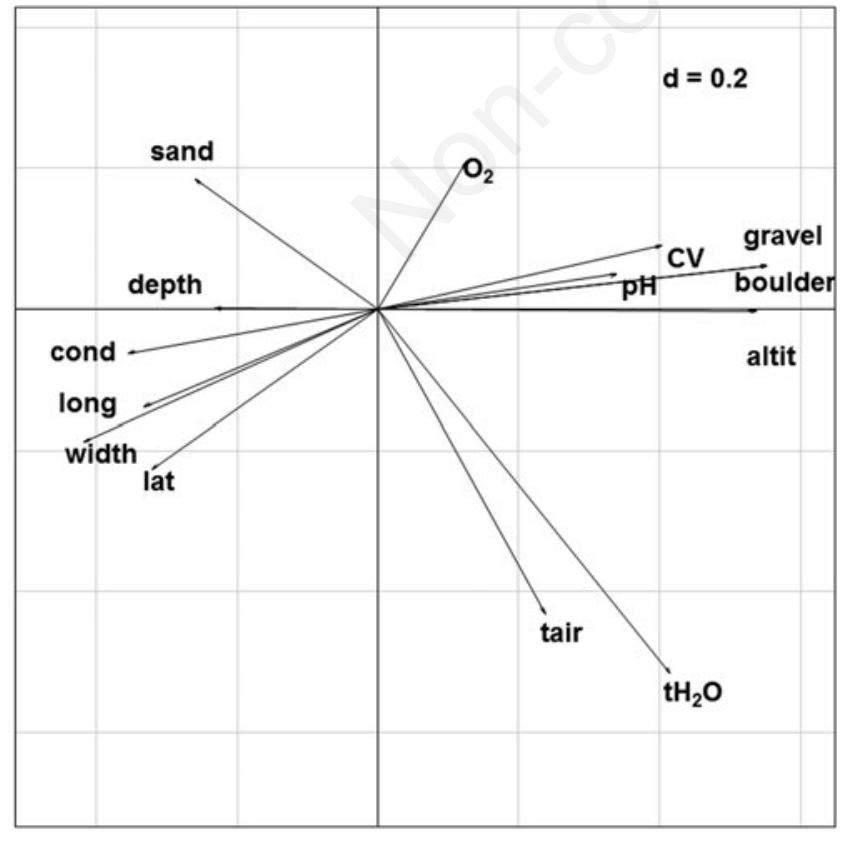

Figure 5. Co-inertia analysis, plot of environmental variables in the first 2 axes.

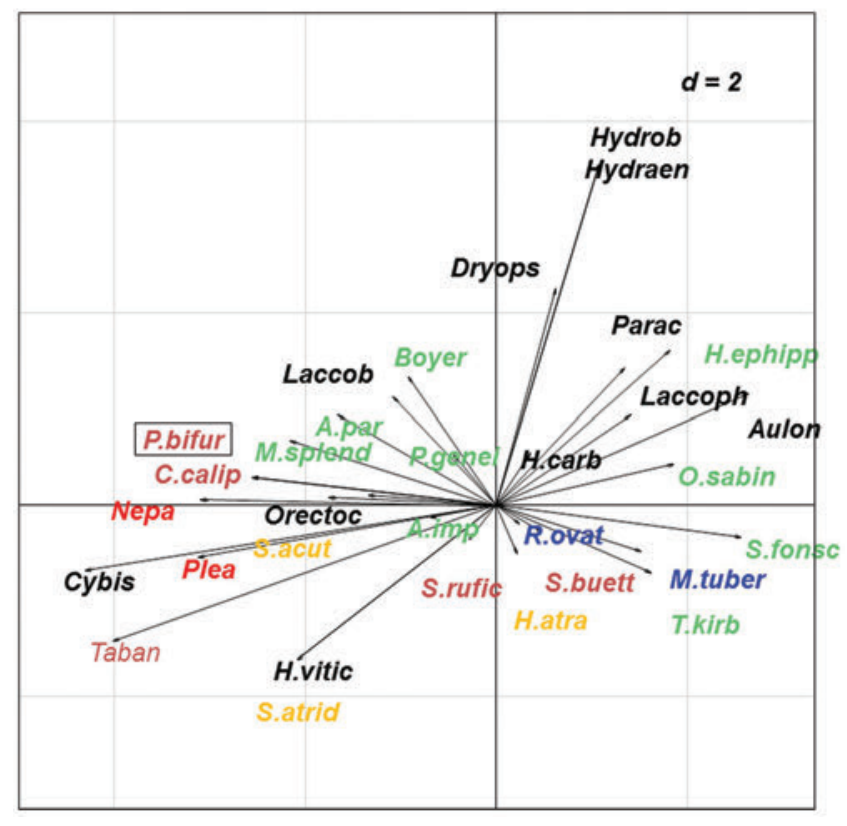

Figure 6. Co-inertia analysis, plot of species in the first 2 axes. 
as its chemical conditions and it is always associated with high rainfall. Current velocity and substrate play a major role in structuring stream communities (Jeffries and Mills, 1990; Williams and Feltmate, 1992) and both these factors are influenced by the flood event. The results presented here represent pre-flood and post-flood conditions.

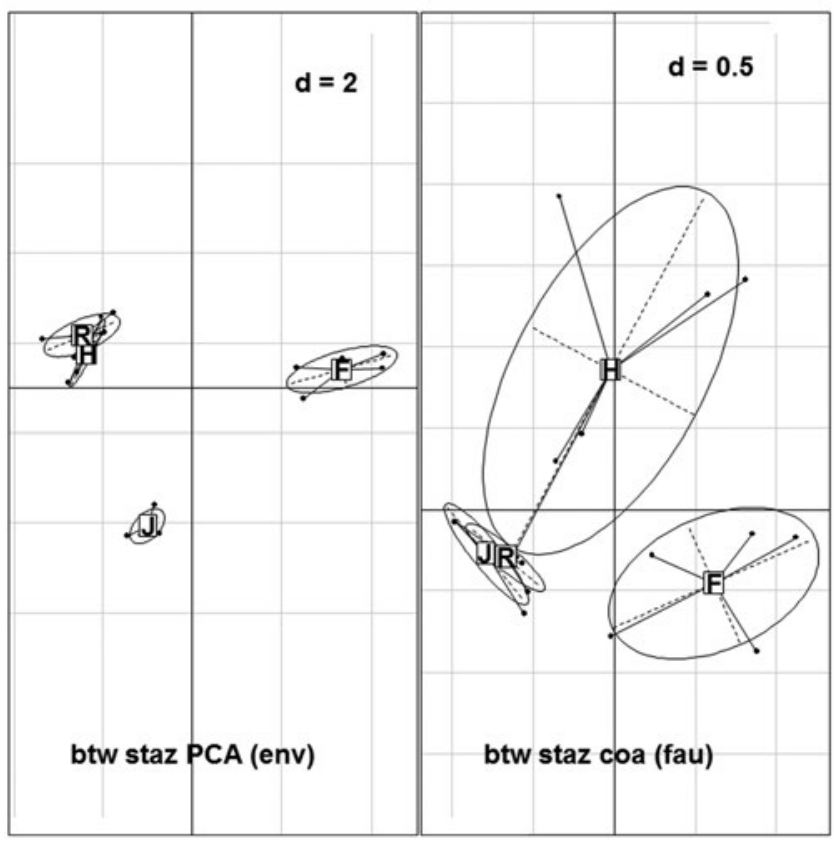

Figure 7. Between station co-inertia analysis, plot of stations in the first 2 axes, left environmental table, right species table.

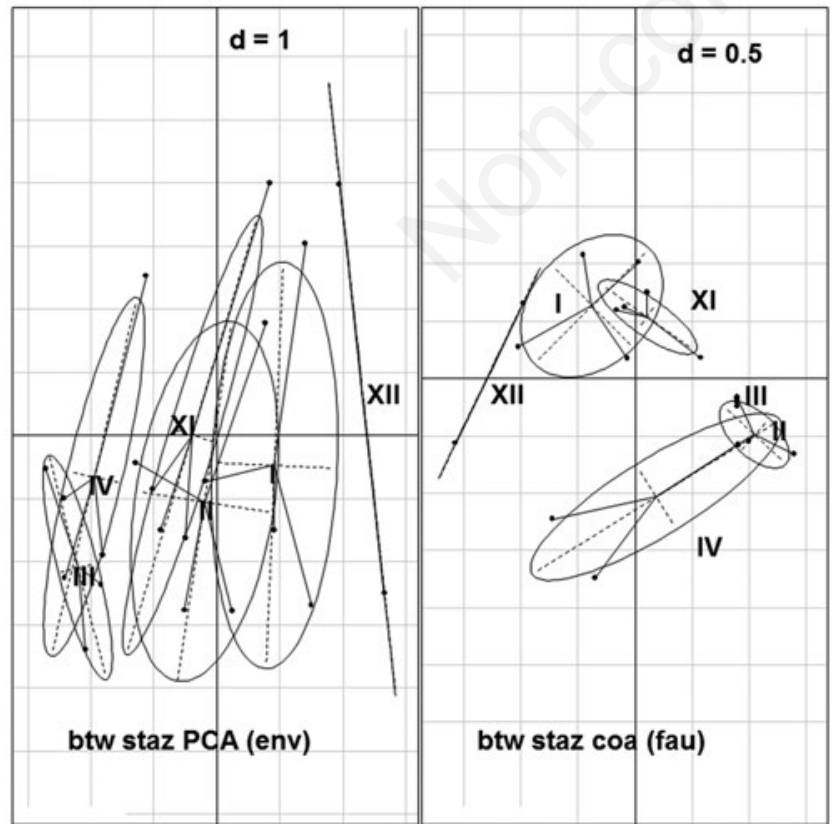

Figure 8. Between month co-inertia analysis, plot of months in the first 2 axes, left environmental table, right species table; months are expressed as Roman numbers.
Substrate, along with current velocity, accounted for differences in the abundance of the major groups of invertebrates (Simuliidae, Pulmonata and Coleoptera) found in the four stations as confirmed by coinertia analysis. Seasonal variations in the abundance of Simuliidae and Chironomidae also reflected the varying colonization potential of the different biotopes in different months.

The water chemistry of running waters is dependent on the physical and geological features of the drainage basin (Bishop, 1973). Water quality conditions directly affect the structure of stream communities (Bunn \& Davies, 1992; Camargo, 1992). The low overall faunal diversity of the streams investigated cannot be attributed to low chemical quality, anthropogenic pressures are almost absent in the area. The chemical parameters estimated here were comprised within the ranges reported in the other waters of the northern Oman Mountains (Stanger, 1986) and in other tropic streams (Ogbeibu \& Victor, 1989; Victor \& Ogbeibu, 1985, 1991). Differences in the distribution and abundance of invertebrates could not be attributed to any specific chemical parameter because the water chemistry did not differ significantly in all biotopes and stations, $\mathrm{pH}$ values higher than 8 , conductiv-

Table 7. Co-inertia analysis results, species scores in the first four axes.

\begin{tabular}{|c|c|c|c|c|}
\hline & CS1 & CS2 & CS3 & CS4 \\
\hline A.imp & -0.482 & -0.162 & 0.953 & 0.630 \\
\hline A.par & -1.161 & 1.157 & 0.398 & 0.217 \\
\hline Boyer & -0.647 & 1.648 & -0.339 & -0.219 \\
\hline H.ephipp & 1.267 & 1.986 & -0.425 & 0.880 \\
\hline Parac & 0.937 & 1.757 & 0.951 & -2.279 \\
\hline O.sabin & 1.292 & 0.528 & -0.685 & 3.946 \\
\hline S.fonsc & 1.784 & -0.417 & -1.414 & 1.777 \\
\hline T.kirb & 1.125 & -0.874 & 1.338 & -4.542 \\
\hline M.splend & -1.503 & 0.829 & 0.890 & 0.508 \\
\hline Nepa & -2.158 & 0.073 & -1.789 & -0.687 \\
\hline R.ovat & 0.170 & -0.236 & -0.613 & 1.080 \\
\hline H.atra & 0.153 & -0.623 & -0.810 & -0.825 \\
\hline S.acut & -1.222 & 0.097 & 0.561 & 0.189 \\
\hline Stenoph & -1.451 & -1.989 & -1.490 & -1.061 \\
\hline C.calip & -1.778 & 0.355 & -3.409 & -1.444 \\
\hline P.genei & -0.312 & 0.638 & -0.604 & -0.228 \\
\hline S.buett & 0.332 & -0.339 & 0.679 & 0.845 \\
\hline S.rufic & -0.201 & -0.439 & 1.512 & -0.563 \\
\hline Taban & -2.799 & -1.750 & 2.610 & 1.629 \\
\hline Aulon & 1.835 & 1.426 & -0.703 & -0.368 \\
\hline Dryops & 0.435 & 2.784 & -0.093 & -0.337 \\
\hline Cybis & -3.001 & -0.842 & 3.187 & 1.960 \\
\hline H.vitic & -1.451 & -1.989 & -1.490 & -1.061 \\
\hline Laccoph & 0.979 & 1.162 & 1.039 & -2.791 \\
\hline P.bifur & -1.778 & 0.355 & -3.409 & -1.444 \\
\hline Hydraen & 0.749 & 4.389 & 0.564 & -0.017 \\
\hline H.carb & 0.252 & 0.669 & -0.158 & -0.446 \\
\hline Hydrob & 0.749 & 4.389 & 0.564 & -0.017 \\
\hline Laccob & -0.755 & 1.389 & -0.290 & -0.316 \\
\hline Plea & -2.173 & -0.672 & -0.784 & -0.364 \\
\hline Orectoc & -0.938 & 0.125 & -0.578 & 1.549 \\
\hline M.tuber & 1.057 & -0.594 & -0.306 & -0.248 \\
\hline
\end{tabular}


ity comprised between 400 and $600 \mu \mathrm{S} \mathrm{cm}-1$ (Table 1) should not be responsible in a reduction in biodiversity.

Thirty two invertebrate taxa recorded in these streams is a low number when compared to other tropical streams. Further taxonomic studies and longer sampling duration may increase the number of taxa to some extent, but it is emphasised that diversity is generally low in physically controlled systems (Odum, 1971), relatively few species are capable of tolerating the harshness of the environmental conditions associated with the hot and arid climate, thus explaining the poor faunal diversity (Lawrence, 1981; Louw \& Seely, 1982; Carl, 1989). The low number of benthic invertebrates recorded here is expected. The irregular flood cycles of streams such as this are an added problem for survival. Pulmonates and Diptera are common and often the major components of many tropical streams, but the latter are usually the dominant taxa (Ogbeibu \& Victor, 1989; Victor \& Ogbeibu, 1985, 1991). In the studied biotopes, Diptera, with a relative abundance of $18-71 \%$, were more abundant than Pulmonata, represented only by $21-67 \%$, while Heteroptera, seldom abundant in tropical streams, accounted for $0-10 \%$. The heterogeneous distribution and abundance of taxa among the different biotopes at the same station is not unusual in temperate and tropical stream. This is a reflection of niche availability governed by physical, chemical and biological factors. All invertebrate taxa recorded in these streams either have terrestrial life stages (aquatic insects) or have adaptations for surmounting unfavourable conditions such as drought (Pulmonata). Most species found are widely distributed, but there are some remarkable exceptions as Polypedilum bifurcatum, Setodes acutus and Simulium buettikeri (see Results), suggesting that the macroinvertebrate fauna of these arid zones merits further study.

There are areas in the world where water deficit is critical and this challenge is seriously aggravated by climate change, so it is urgent to deepen our knowledge of these areas; the arid zone of Northern Oman must be surely qualified as a region of high interest and the scarcity of work on these areas, makes the need of further work impelling.

\section{References}

ADLER P.H., CROSSKEY R.W., 2013 - World Blackflies (Diptera: Simuliidae): a comprehensive revision of the taxonomic and geographical inventory. - Available from: http://www.clemson.edu/cafls/ biomia/pdfs/blackflyinventory.pdf

ARAB A., LEK S., LOUNACI A., PARK Y.S., 2004 - Spatial and temporal patterns of benthic invertebrate communities in an intermittent river (North Africa). - Annal. Limnol. Int. J. Limnol. 40: 317-327.

BENDATI M.M.A., MAIZONAVE C.R.M., OLABARRIAGA E.D., ROSAD0 R.M., 1998 - Use of the benthic macroinvertebrate community as a pollution indicator in the Gravataí River (RS, Brazil). - Verh. Int. Ver. Limnol. 26: 2019-2023.

BISHOP J.E., 1973 - Limnology of a Small Malayan River Sungai Gombok. - Monographiae Biologicae, The Hague. 22: 485 pp.

BORCARD D., GILLET F., LEGENDRE P., 2011 - Numerical ecology with R. - Springer, New York/Heidelberg: $301 \mathrm{pp}$.

BOULTON A.J., LAKE P.S., 1992a - The ecology of two intermittent streams in Victoria, Australia. Comparisons of faunal composition between habitats, rivers and years. - Freshwat. Biol. 27: 99-121.

BOULTON A.J., LAKE P.S., 1992b - The ecology of two intermittent streams in Victoria, Australia. Temporal changes in faunal composition. - Freshwat. Biol. 27: 123-138.

BOUMAÏZA M., 1994 - Recherche sur les eaux courantes de Tunisie. Faunistique, écologie et biogéographie. Thèse de Doctorat d'Etat Es-Sciences Biologiques. - Fac. Sci. Tunis: 427 pp.

BR00KS R.T., 2000 - Annual and seasonal variation and the effects of hydroperiod on benthic macroinvertebrates of seasonal forest ("vernal") ponds in central Massachusetts, USA. - Wetlands. 20: 707-715.

BUNN S.E., DAVIES P.M., 1992 - Community structure of macroinvertebrate fauna and water quality of a saline river system in southwestern Australia. - Hydrobiologia 248: 143-160.

BURT J., 2003 - Aquatic macroinvertebrates of an intermittent stream in the arid Hajar Mountains, Oman. - Tribulus 13: 14-22.

CAMARGO J.A., 1992 - Structural and trophic alterations in macrobenthic communities downstream from a fish farm outlet. Hydrobiologia 242: 41-49.

CARL M., 1989 - The ecology of a wadi in Iraq with particular reference to colonization strategies of aquatic macroinvertebrates. - Arch. Hydrobiol. 116: 499-515.

CHAIB N., BOUHALA Z., FOUZARI A., MARZIALI L., SAMRAOUI B., ROSSARO B., 2013a - Environmental factors affecting the distribution of Chironomid larvae of the Seybouse wadi, Northeastern Algeria. - J. Limnol. 72: 203-214.

CHAIB N., FOUZARI A., BOUHALA Z., SAMRAOUI B., ROSSARO B., 2013b - Chironomid (Diptera, Chironomidae) species assemblages in north Eastern Algerian hydrosystems. - J. Entomol. Acarol. Res. 45: 4-11.

CHAM S., 2007 - Field guide to the larvae and exuviae of British dragonflies (Volume 1: Dragonflies Anisoptera). - British Dragonfly Society, Norfolk: 80 pp.

CHAM S., 2009 - Field guide to the larvae and exuviae of British dragonflies (Volume 2: Dragonflies Zygoptera). - British Dragonfly Society, Norfolk: 76 pp.

DAKKI M., 1979-80 - Contribution a la connaissance des Leptocerides (Trichoptera) du Maroc. - Bull. Inst. Sci. Rabat 4: 41-52.

DE SHON J.E., 1995 - Development and application of the invertebrate community index (ICI). In: DAVIS W.S., SIMON T.P. (Eds.), Biological assessment and criteria. - Lewis Publ., UK: 217-243.

DEPIEREUX E., FEYTMANS E., MICHA J.C., 1983 - Utilisation critique de l'analyse en composantes principales et du cluster analysis pour la description d'échantillons d'invertébrés benthiques en eau douce. - Oikos 40: 81-94.

FISHER S.G., GRAY L.J., GRIMM N.B., BUSCH D.E., 1982 - Temporal succession in a desert stream ecosystem following flash flooding. Ecol. Monogr. 52: 93-110.

FRANQUET E., DOLEDEC S., CHESSEL D., 1995 - Using multivariate analyses for separating spatial and temporal effects within speciesenvironment relationships. - Hydrobiologia 300/301: 425-431.

FRIDAY L.E., 1988 - A key to the adults of British water beetles. - Field Stud. 7: 1-151.

GIROD A., BIANCHI I., MARIANI M., 1980 - Gasteropodi 1 (Gastropoda: Pulmonata; Prosobranchia: Neritidae, Viviparidae, Bithyniidae, Valvatidae). In: RUFFO S. (Ed.), Guide per il riconoscimento delle specie animali delle acque interne italiane. - C.N.R. AQ/1/44 7 Consiglio Nazionale delle Ricerche, Roma, Italy: 86 pp.

GOWER A.M., MYERS G., KENT M., FOULKES M.E., 1994 - Relationships between macroinvertebrate communities and environmental variables in metal-contaminated streams in south-west England. Freshwat. Biol. 32: 199-221.

HEIDEMANN H., SEIDENBUSCH R., 2002 - Larves et Exuvies des Libellules de France et d'Allemagne (sauf de Corse). - Boys d'Arcy, France: 415pp.

JEFFRIES M., MILLS D., 1990 - Freshwater ecology. Principles and applications. - Belhaven Press, London: 285 pp.

LAUNAY F., JUNGIUS H., 2001 - Biodiversity conservation in the UAE. World Wildlife Fund for Nature.

LAWRENCE J., 1981 - Postflood recolonization pathways of macroinvertebrates in a lowland Sonoran desert stream. - Am. Midland Naturalist. 106: 249-257.

LEGENDRE P., LEGENDRE L., 1998 - Numerical ecology. Developments in numerical modelling 20. - Elsevier, Amsterdam: 853 pp. 
LOUW G.N., SEELY M.K., 1982 - Ecology of desert organisms. Longman, London: 194 pp.

LUDWIG J.A., REYNOLD J.F., 1988 - Statistical ecology. A primer on methods and computing. - John Wiley Sons, New York: 337 pp.

LUPI D., ROCCO A., ROSSARO B., 2013 - Benthic macroinvertebrates in Italian rice fields. - J. Limnol. 72: 184-200.

METCALFE-SMITH J.L., 1996 - Biological water-quality assessment of rivers: use of macroinvertebrate communities. In: PETTS G. and CALOW P. (Eds.), River restoration. - Blackwell Science, Oxford: 17-43.

MORETTI G.P., 1983 - Tricotteri (Trichoptera). In: RUFFO S. (Ed.), Guide per il riconoscimento delle specie animali delle acque interne italiane. - C.N.R AQ/1/196 Vol 19. Consiglio Nazionale delle Ricerche, Roma, Italy: 155 pp.

NOCENTINI A., 1985 - Chironomidi, 4 (Diptera, Chironomidae: Chironominae, larve). In: RUFFO S. (Ed.), Guide per il riconoscimento delle specie animali delle acque interne italiane. - C.N.R. AQ/1/233, N. 29. Consiglio Nazionale delle Ricerche, Roma, Italy: 186 pp.

ODUM E.P., 1971 - Fundamentals of ecology. 3rd ed. - W.B. Sanders, London: $546 \mathrm{pp}$.

OGBEIBU A.E., VICTOR R., 1989 - The effect of road and bridge construction onbankroot macrobenthic invertebrates. - Environ. Pollut. 56: $58-100$.

OLMI M., 1978 - Driopidi, elmintidi (Coleoptera Dryopidae, Elminthidae). In: RUFFO S. (Ed.), Guide per il riconoscimento delle specie animali delle acque interne italiane. - C.N.R. AQ/1/6 2. Consiglio Nazionale delle Ricerche, Roma, Italy: $71 \mathrm{pp}$.

ORMEROD S.J., 1987 - The influence of habitat and seasonal sampling regimes on the ordination and classification of macroinvertebrate assemblages in the catchment of the River Wye, Wales. Hydrobiologia 50: 143-151.

ORMEROD S.J., EDWARDS R.W., 1987 - The ordination and classification of macroinvertebrate assemblages in the catchment of the River Wye in relation to environmental factors. - Freshwat. Biol. 17: 533-546.

PECH N., LALOË F., 1997 - Use of principal component analysis with instrumental variables (PCAIV) to analyse fisheries catch data. ICES J. Marine Sci. 54: 32-47.

PIRISINU Q., 1981 - Palpicorni (Coleoptera: Hydraenidae, Helophoridae, Spercheidae, Hydrochidae, Hydrophilidae, Sphaeridiidae). In: RUFFO S. (Ed.), Guide per il riconoscimento delle specie animali delle acque interne italiane. - C.N.R. AQ/1/128 Vol 13. Consiglio Nazionale delle Ricerche, Roma, Italy: 96 pp.
RESH V.H., 1995 - Freshwater benthic macroinvertebrates and rapid assessment procedures for water quality monitoring in developing and newly industrialized countries. In: DAVIS W.S. and SIMON T.P. (Eds.), Biological assessment and criteria. - Lewis Publ., UK: 167-177.

RESH V.H., BROWN A.V., COVICH A.P., GURTZ M.E., LI H.W., MINSHALL G.W., REICE S.R., SHELDON J.B., WISSMAR R.C., 1988 - The role of disturbance in stream ecology. - J. N. Am. Benthol. Soc. 7: 433-455.

SCRIMGEOUR G.J., WINTERBOURN M.J., 1989 - Effects of floods on epilithon and benthic macroinvertebrate populations in an unstable New Zealand river. - Hydrobiologia 171: 33-44.

SOUSA W.P., 1984 - The role of disturbance in natural communities. Ann. Review Ecol. Syst. 15: 353-391.

STANGER G., 1986 - The hydrogeology of Oman Mountains, vol 1 and 2, Ph.D. thesis. - The Open University, UK: 679 pp.

TAMANINI L., 1979 - Eterotteri acquatici (Heteroptera: Gerromorpha, Nepomorpha). In: RUFFO S. (Ed.), Guide per il riconoscimento delle specie animali delle acque interne italiane. - C.N.R. AQ/1/45 6. Consiglio Nazionale delle Ricerche, Roma, Italy: 106 pp.

TATE C.M., HEINY J.S., 1995 - The ordination of benthic invertebrate communities in the South Platte River Basin in relation to environmental factors. - Freshwat. Biol. 33: 439-454.

VÅRDAL H., BJØRLO A., SÆTHER 0.A., 2002 - Afrotropical Polypedilum subgenus Tripodura, with a review of the subgenus (Diptera: Chironomidae). - Zool. Scripta. 31: 331-402.

VICTOR R., AL-MAHROUQI A.I.S., 1996 - Physical, chemical and faunal characteristics of a perennial stream in arid northern Oman. - J. Arid Environ. 34: 465-476.

VICTOR R., OGBEIBU A.E., 1985 - Macrobenthic invertebrates of a Nigerian stream flowing through farmland in Southern Nigeria. Environ. - Pollut. Ser. 39: 337-349.

VICTOR R., OGBEIBU A.E., 1991 - Macroinvertebrate communities in the erosional biotope of an urban stream in Nigeria. - Trop. Zool. 4: 1-12.

WILLIAMS D.D., FELTMATE B.W., 1992 - Aquatic insects. - C.A.B. 49 International, Wallingford: $358 \mathrm{pp}$.

WRIGHT J.F., ARMITAGE P.D., MOSS D., FURSE M.T., 1984 - A preliminary classification of running-water sites in Great Britain based on macro-invertebrate species and the prediction of community type using environmental data. - Freshwat. Biol. 14: 221.256.

ZAR J.H., 1984 - Biostatistical Analysis. - Prentice Hall, USA: 718 pp.

ZERGUINE K., SAMRAOUI B., ROSSARO B., 2009 - A survey of Chironomids from seasonal ponds of Numidia, northeastern Algeria. - Boll. Zool. Agr. Bachicol. 41: 167-174. 